80. 多孔質弾性舗装の反射特性に関する検討

伊東 勇人 鈴木 徹 大橋 利彦

（松下電工株式会社）
石倉 丈士

(建設省 土木研究所)
竹之内 光彦

（星和電機株式会社）

1. はじめに

道路照明設計における路面輝度は、重要な照明要件の一つであり、設計条件に応じた所要路面輝度 を確保できるよつに照明器具の配置計画がおこなわれる。しかし、同一の照明条件下であっても舗装 の種類によって路面の反射特性が異なることから舗装の種類を考慮して照明設計をおこなう必要があ る。わが国における道路照明設計の規格である「道路照明施設設置基準・同解説（以下、設置基準とす る）」では、舗装の種類をコンクリート舗装とアスファルト舗装に分類し、各々の平均照度換算係数が 定義されている。

最近、近年の交通事情や道路周辺の環境に配虑し、小片に裁断した使用済みタイヤのゴムチップを ウレタン樹脂で固め板状にしたものを路面表層に敷詰めた「多孔質弾性舗装」の開発が進められてい る。この舗装は、水密性が低く、滞水し難いことから雨天時の視認性に優れ、タイヤと路面の接触に よる騒音の低減効果が大きい特徵を有し、実用化に向けて各種性能の評価、検討が進められている。 しかし、道路照明設計において必要な反射特性については明らかにされていない。

本報では、多孔質弾性舗装及び従来の道路舗装に用いられてきた密粒アスファルト舗装の光学測定 をおこない、反射特性の傾向について明らかにするとともに、C I Eによる分類方法を用いた輝度換 算係数の分布表（r-table）との比較検討をおこなったので報告する。

\title{
2. 測定の概要
}

本報では、反射率、平均照度換算係数、総合均斉度、車線軸均斉度及び鏡面係数 $\mathrm{S} 1$ 等の反射特性 を把握するために必要な光学測定をおこなった。ここで、鏡面係数Ｓ１は、路面舗装のつやの状態を 示し、C I E ${ }^{1)}$ において式1のよjに定義されている。

$$
\mathrm{S} 1=\mathrm{r}(0 、 2) / \mathrm{r}(0 、 0)
$$

ここで、 $\mathrm{r}(0 、 0)$ ：照明器具直下の輝度換算係数、 $\mathrm{r}(0 、 2)$ ：照明器具直下を通る道路軸 に平行な直線上で、照明器具直下から観測者の方向に向かって照明器具の取付け高さの 2 倍の距離だ け離れた位置における輝度換算係数

測定は、建設省土木研究所の試験走路を用いておこなった。以下に測定の概要を示す。

1）照明施設

- 照明器具：K S C - 4 (セミカットオフ）

・ランプ：蛍光水銀ランプ $400 \mathrm{~W}$

・設置高さ：10 m

・設置間隔：35 m

・設置台数：5台

・オーバーハング：0 m

・配列：片側配列

$2 ）$ 舗装

表 -1 舗装の種類

\begin{tabular}{|c|c|c|c|}
\hline & 舗装 1 & 舗装 2 & 舗装 3 \\
\hline 舗装の種類 & $\begin{array}{c}\text { 多孔質 } \\
\text { 弾性舗装 }\end{array}$ & $\begin{array}{c}\text { 多孔質 } \\
\text { 弾性舗装 }\end{array}$ & $\begin{array}{c}\text { 密粒アスフアル卜 } \\
\text { 舗装 }\end{array}$ \\
\hline 空隙率 & $40 \%$ & $40 \%$ & $5 \%$ \\
\hline 粒度 & 小 & 大 & 一 \\
\hline 経過年数 & 2 年 & 2 年 & 20 年 \\
\hline
\end{tabular}

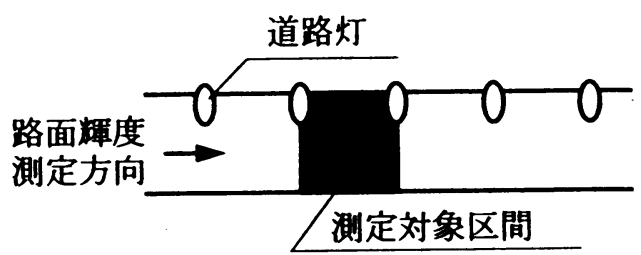

図-1 路面照度、路面輝度の測定区間

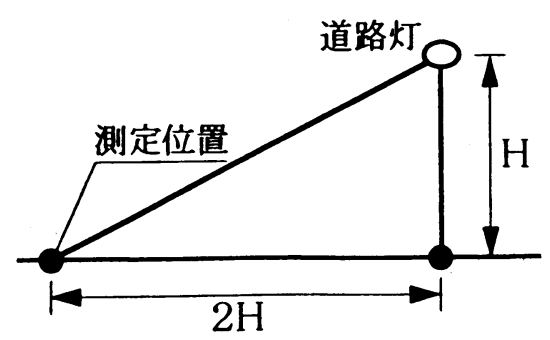

図-2 鏡面係数 $\mathrm{S} 1$ を求めるための 路面照度、路面輝度の測定位置 


\section{平成 11 年度照明学会第 32 回全国大会}

3 ）測定項目

·路面照度、路面輝度の測定：

平均照度、平均路面輝度、総合均斉度を把握するために図ー 1 に示す測定対象区間におい て路面照度と路面輝度を測定した。測定位置は、縦断方向に 7 ヶ所、横断方向に 3 ヶ所の計 21 ケ所とした。路面輝度は、図ー1の矢印の方向を観測方向として測定した。

また、鏡面係数 S 1 を求めるために図一 2 に示す器具直下を通る道路軸に平行な 2 点の路 面照度と路面輝度を測定した。

- 反射率：

\section{3. 測定結果}

反射率は、色彩色差計（拡散照明・垂直受光方式、D 65 光源）により測定した。

光学測定の結果を表一 2 に示す。反射率は、 2 種類の多孔質弾性舗装はほほ同じ值であるが、密 粒アスファルトは多孔質弾性舗装に比べて約 3.3 倍高い值であった。平均水平面照度及び照度 の総合均斉度は、3 種類の舗装ともほほ同じ值を 示し、同等の照明環境下において路面照度測定が おこなわれたことを示す。平均路面輝度は、2 種 類の多孔質弾性舗装はほほ同等であるが、密粒ア スファルトは多孔質弾性舗装に比べて約 $65 \%$ 程 度高い值であった。平均照度換算係数も、2 種類 の多孔質弾性舗装はほほ同等であるが、密粒アス ファルトは多孔質弾性舗装に比べて約 $40 \%$ 程度 小さい值であった。また、設置基準では密粒アス ファルトの平均照度換算係数が、 $15\left(1 \mathrm{x} / \mathrm{cd} / \mathrm{m}^{2}\right)$

\begin{tabular}{|c|c|c|c|c|}
\hline & & 舗装 1 & 舗装 2 & 舗装 3 \\
\hline \multicolumn{2}{|c|}{ 反射率 } & 2.6 & 2.5 & 8.4 \\
\hline \multirow{2}{*}{$\begin{array}{l}\text { 照 } \\
\text { 度 }\end{array}$} & 平均 $(\mathrm{lx})$ & 25.3 & 25.8 & 26.2 \\
\hline & 総合均斉度 & 0.51 & 0.56 & 0.53 \\
\hline \multirow{2}{*}{$\begin{array}{l}\text { 輝 } \\
\text { 度 }\end{array}$} & 平均 $\left(\mathrm{cd} / \mathrm{m}^{2}\right)$ & 1.06 & 0.99 & 1.65 \\
\hline & 総合均斉度 & 0.58 & 0.69 & 0.66 \\
\hline \multicolumn{2}{|c|}{$\begin{array}{l}\text { 平均照度換算係数 } \\
\left(\mathrm{l} x / \mathrm{cd} / \mathrm{m}^{2}\right)\end{array}$} & 23.9 & 26.1 & 15.9 \\
\hline \multicolumn{2}{|c|}{ 平均輝度係数 } & 0.042 & 0.038 & 0.063 \\
\hline \multicolumn{2}{|c|}{ 鏡面係数 S 1} & 1.05 & 0.77 & 0.51 \\
\hline
\end{tabular}
った。

平均輝度係数を平均照度換算係数の逆数として求めると、多孔質弾性舗装に比べて密粒アスファル トは約 1.5 倍高く、鏡面係数は、反対に多孔質弾性舗装の方が、約 1.5〜2.0 倍高かった。

\section{4. r-table の分類}

表一 3 に鏡面係数 S 1 に基づく r-table の分類 結果を示す。C分類では 3 種類の舗装ともC 2 に 分類され、 $\mathrm{R}$ 分類では 2 種類の多孔質弾性舗装に おいてR 3 とR 2 の異なるクラスに分類された。 N分類では多孔質弾性舗装がN 3 に分類され、密 粒アスファルトはN 2 に分類された。

表－3 CIE による r-table の分類結果

\begin{tabular}{|l|l|l|l|}
\hline & 舗装 1 & 舗装 2 & 舗装 3 \\
\hline $\mathrm{C}$ 分類 & $\mathrm{C} 2$ & $\mathrm{C} 2$ & $\mathrm{C} 2$ \\
\hline $\mathrm{R}$ 分類 & $\mathrm{R} \mathrm{3}$ & $\mathrm{R} 2$ & $\mathrm{R} 2$ \\
\hline $\mathrm{N}$ 分類 & $\mathrm{N} \mathrm{3}$ & $\mathrm{N} 3$ & $\mathrm{~N} 2$ \\
\hline
\end{tabular}

\section{5. まとめ}

光学測定の結果から、多孔質弾性舗装は、アスファルト舗装に比べて平均照度換算係数が大きくな り同等の路面輝度を確保するためにはより多くの照度が必要になることがわかった。また、多孔質弾 性舗装は、アスファルト舗装に比べて鏡面性が高く総合均斉度がやや低くなる傾向にあった。鏡面性 に基づくC I Eの r-table の分類方法を用いると、C分類では 3 つ舗装が同一のクラスに分類され たが、C分類よりクラス数の多い $\mathrm{R} 、 \mathrm{~N}$ 分類では、鏡面係数によって異なるクラスに分類された。

\section{参考文献}

1) CIE Pub No.66 ROAD SURFACES AND LIGHTING, 1984

A Study of Reflection Properties for Porous Elastic Road Surface

Hayato Ito, Toru Suzuki, Toshihiko Ohhasi, Takeshi Ishikura, Mituhiko Takenouchi 